\title{
Effect of herbicides on growth, nodulation and nitrogen content of greengram
}

\author{
Almas ZAIDI ${ }^{a}$, Md. Saghir KHAN*, Pervez Qamar RIZVI ${ }^{\mathrm{b}}$ \\ ${ }^{a}$ Department of Agricultural Microbiology, Institute of Agricultural Sciences, Aligarh Muslim University, Aligarh 202002, India \\ ${ }^{\mathrm{b}}$ Department of Plant Protection, Institute of Agricultural Sciences, Aligarh Muslim University, Aligarh 202002, India
}

(Accepted 10 June 2005)

\begin{abstract}
We studied the effects of glyphosate, metribuzin, fluchloralin and 2,4-dichlorophenoxy-acetic acid (2,4-D) on plant vigor, nodulation, photosynthetic pigments, $\mathrm{N}$ content, seed yield and protein content in seeds, in greengram inoculated with Bradyrhizobium sp. (vigna). The pre-emergence application of the four herbicides, at $2 \mu \mathrm{g} \mathrm{a.i.} \mathrm{g}^{-1}$ of soil, adversely affected the parameters. The average maximum increase of $12.5 \%$ in seed yield occurred at $0.5 \mu \mathrm{g}$ a.i. $\mathrm{g}^{-1}$ of glyphosate, while metribuzin at 0.5 and $1 \mu \mathrm{g} \mathrm{a.i.} \mathrm{g}^{-1}$ decreased the seed yield by 33.3 and $55.5 \%$, respectively. The average maximum chlorophyll content of $3.41 \mathrm{mg} / \mathrm{g}$ was obtained at $0.5 \mu \mathrm{g}$ a.i. $\mathrm{g}^{-1}$ (fluchloralin), which declined consistently for all herbicides and increasing dose rates. Glyphosate at $0.5 \mu \mathrm{g} \mathrm{a.i.} \mathrm{g}^{-1}$ increased the number of nodules formed per plant by $12.5 \%$ and $14.3 \%$ at 35 and 60 days after seeding the greengram. In contrast, metibuzin $\left(0.5\right.$ and $1 \mu \mathrm{g}$ a.i. $\left.\mathrm{g}^{-1}\right)$ and the higher rates of $2 \mu \mathrm{g}$ a.i. $\mathrm{g}^{-1}$ of glyphosate, fluchloralin and 2,4-D significantly reduced the nodulation (nodule number and dry mass). The average maximum grain protein of $24 \%$ was obtained for glyphosate at $0.5 \mu \mathrm{g}$ a.i. $\mathrm{g}^{-1}$ while minimum grain protein was obtained at $0.5(10 \%)$ and $1 \mu \mathrm{g}$ a.i. $\mathrm{g}^{-1}(8 \%)$ of metribuzin application. Nitrogen content in whole plants decreased gradually with herbicide rates both at 35 and 50 days after seeding. Among the herbicides tested, metribuzin showed a large degree of phytotoxicity to the crop, inhibiting its vegetative growth, and was thus incompatible with greengram.
\end{abstract}

greengram / herbicides / nodulation / seed protein

\section{INTRODUCTION}

Greengram [Vigna radiata $(\mathrm{L}$.) wilczek] productivity often suffers from weed competition, thus requiring herbicides to be used widely. In addition, rhizobial inoculants are applied to the seeds or soil to ensure effective nodulation and subsequent $\mathrm{N}_{2}$ fixation in greengram plants. Although reports on herbicidal impact on legumes are conflicting, several studies have conclusively shown that some of these chemicals are incompatible with Rhizobium (Singh and Wright, 2002; Aamil et al., 2004).

The toxicological effects of various herbicides on legumes have been reported (Khan et al., 2004). The magnitude of the toxic effects of herbicides, however, depends primarily on the type and dose of compounds, duration of exposure, species and age of plants, and other environmental factors. Thus herbicides, when applied under field conditions, can affect both the rhizobia and their symbiosis with legume crops, e.g., metribuzin affects the Rhizobium sp. (Heinonen-Tanski et al., 1982), the plant (Rennie and Dubetz, 1984) and the legume - Rhizobium symbiosis (Malik and Tesfai, 1985). However, the data regarding the negative effect of metribuzin and other photosynthesisinhibiting herbicides on the legume-Rhizobium spp. symbiosis are contradictory (Avron, 1966). In field studies with the recommended and five times more than the recommended dose of metribuzin and alachlor, a significant reduction in nodulation, nitrogenase activity and total $\mathrm{N}$ content in soybean was reported (Malik and Tesfai, 1985). Similarly, the recommended and double the recommended rates of metribuzin inhibited vegetative growth, nodulation and nitrogen fixation in cowpea [Vigna unguiculata (L.) walp]. However, the herbicides did not adversely affect the nitrogen uptake (Silva et al., 1998).

In field studies, fluchloralin and pendimethalin adversely affected nodulation in inoculated greengram and pigeonpea (Pahwa et al., 1988) and soybean (Bollich et al., 1985). In contrast, a significant increase in dry matter accumulation in soybean following pendimethalin application in a $B$. japonicuminoculated crop in a two-year field trial was reported (Billore et al., 2001). The recommended and double dose of fluchloralin improved nodulation, grain and straw yield of soybean (Pandey and Rai, 1995), while double the recommended rates of 2,4-D and isoproturon adversely affected the plant growth, photosynthetic pigments, nodulation, $\mathrm{N}$ content and yield of chickpea (Aamil et al., 2002). Conversely, double the recommended rates of fluchloralin increased the seed yield in chickpea. Similarly, fluchloralin, bentazone, isoproturon and 2,4-D at ten times the recommended dose rates substantially reduced the seed yield in chickpea (Khan et al., 2004).

\footnotetext{
* Corresponding author: khanms17@ rediffmail.com
} 
Fluchloralin at recommended rates increased nodulation in groundnuts, whereas the same rate of benefin, dinitroamine and nitralin decreased nodule dry mass, nitrogenase activity, yield and total $\mathrm{N}$ content of the tops, under field and greenhouse conditions (Durgesha, 1994). Fuchloralin and metribuzin applied at $1.5 \mathrm{~kg} / \mathrm{ha}$ and $0.75 \mathrm{~kg} / \mathrm{ha}$, respectively, substantially reduced the roots and shoots and nodulation in chickpea (Pahwa and Prakash, 1992). Glyphosate at 2, 5 and $10 \mu \mathrm{g} \mathrm{g}^{-1}$ soil decreased $\mathrm{C}_{2} \mathrm{H}_{2}$ reduction, nodule numbers and root weights of subterranean clover (Eberbach and Douglas, 1983) and inhibited bacteroid nitrogenase activity of Bradyrhizobium japonicum strains (Hernandez et al., 1999). Glyphosate has also been found to inhibit Rhizobium spp. in pure culture at a high application rate (Malik and Tesfai, 1983) but not when applied at very high rates $\left(>100 \mathrm{mg}\right.$ a.i. $\mathrm{kg}^{-1}$ ) in field experiments (Malik and Tesfai, 1985).

Geengram is grown widely in the tropics on loamy and sandy loamy soils and fixes $30-40 \mathrm{~kg} \mathrm{~N} / \mathrm{ha}$. In India, greengram occupies an area of three million hectares, accounting for one million tonnes of production, while the average yield of greengram cv. K-851 is $10-12$ q/ha. Greengram contains carbohydrate $(62.6 \%)$, crude protein $(24 \%)$, fat $(1.15 \%)$, ash $(3.32 \%)$, food energy (347 cal), digestibility (79\%) and biological coefficient (72\%) (Sharma, 2000). Greengram thus provides the dual benefit of pulse grain and can be used as green manure. Agronomists therefore desire to maximize the greengram production without compromising the use of herbicides. Although reports have suggested a negative impact of herbicides on field-grown legumes, these chemicals are still widely used during greengram cultivation to prevent losses due to broad and narrow leaf weeds. However, there is relatively little information available on the herbicidal impact on greengram productivity. The present study, therefore, assessed the effects of soil applications of four herbicides, Glyphosate [N-(phosphonomethyl) glycine], Fluchloralin [N-2 (chloroethyl)- $\alpha, \alpha,-\alpha$ (trifluro-2,6-dinitropropyl- $\rho$-toluidine], Metribuzin [4-amino-6-tert-butyl-4, 5dihydro-3-methylthio-1,2,4-triazin-5-one $]$ and 2,4-D [(2,4dichlorophenoxy) acetic acid] on plant vitality, nodulation, $\mathrm{N}$ content, grain protein and yield of greengram, grown under controlled conditions in clay pots.

\section{MATERIALS AND METHODS}

\subsection{Inoculation and plant culture}

Bradyrhizobium sp. (vigna), obtained from the Indian Agricultural Research Institute, New Delhi, India, was grown in yeast extract mannitol broth in flasks shaken at $125 \mathrm{rpm}$ at $28{ }^{\circ} \mathrm{C}$ for six days to a cell density of $4 \times 10^{8}$ cells per $\mathrm{mL}$. Seeds of greengram (cv. K-851) were surface-sterilized (70\% ethanol, $3 \mathrm{~min}$; $3 \%$ sodium hypochlorite, $3 \mathrm{~min}$ ), rinsed six times with sterile water and air-dried. The sterilized seeds were then bio-primed (inoculated) with Bradyrhizobium sp. (vigna) by soaking the seeds in liquid culture medium for $1 \mathrm{~h}$ using $10 \%$ gum arabic solution as a sticker to deliver $\cong 10^{8}$ cells per seed. Glyphosate, metribuzin, fluchloralin and 2,4-D were evaluated at $0.5 \mu \mathrm{g}$ a.i. $\mathrm{g}^{-1}, 1 \mu \mathrm{g}$ a.i. $\mathrm{g}^{-1}$ and $2 \mu \mathrm{g}$ a.i. $\mathrm{g}^{-1}$ of soil. Since surfactants and adjuvants used in the commercial formulations themselves are toxic to the plants (Towne et al., 1978;
McWhorter, 1985) and may contribute to the overall phytotoxicity of a herbicide treatment, all herbicides used in this study, therefore, were of technical grade (purity $>90 \%$ ). The herbicides were added as a pre-sowing application to moist soil $24 \mathrm{~h}$ before sowing and well incorporated in the soil in each clay pot (25 cm high and $22 \mathrm{~cm}$ internal diameter). Bio-primed seeds were sown in each pot (10 seeds/pot) containing $12.5 \mathrm{~kg}$ autoclaved sandy clay loam soil [alluvial, $\mathrm{pH} 7.2, \mathrm{P}\left(\mathrm{NaHCO}_{3}\right.$ extractable) $16 \mathrm{mg} / \mathrm{kg}$, total N $0.75 \mathrm{~g} / \mathrm{kg}$, Organic C $0.4 \%$, WHC, $0.44 \mathrm{~mL} / \mathrm{g}]$. The sowing was done on 15 March 2002 and was repeated with the same herbicides and dose rates on 20 March 2003 using identical environmental conditions. No herbicides were used on the soil before. Pots without herbicide treatments but with inoculated seeds were used as control treatments for comparison. The pots were arranged in a complete randomized block design with nine replications of each treatment. One week after emergence (WAE), plants in each pot were thinned to four plants. The pots were hand-weeded at regular intervals, watered on a daily basis using distilled water and at 10-day intervals with $100 \mathrm{~mL}$ half-strength $\mathrm{N}$-free Hoagland nutrient solution (Hoagland and Arnon, 1938) per pot and were maintained in a greenhouse at $25 \pm 2{ }^{\circ} \mathrm{C}$ and $60 \%$ relative humidity. The experiment was conducted for two consecutive years to ensure the reproducibility of the results.

\subsection{Plant growth, nodulation, chlorophyll content, $\mathrm{N}$ content and seed yield}

All plants in three pots for each treatment were uprooted 35 (flowering stage) and 60 days (pod-fill stage) after seeding, and were used for destructive plant analysis to record nodulation. The roots were carefully washed, and nodules were removed, counted, oven-dried and weighed. Plants uprooted at 60 days after seeding (DAS) were also used for the measurement of root and shoot length and oven-dried before the weights of roots and shoots and plant biomass were determined. The remaining pots, each containing four plants, of all treatments, were maintained until harvest. Pods were picked at weekly intervals (from 65 DAS onwards) during a morning session to avoid shattering and plants were finally harvested 75 DAS and seed yield and grain protein $(\mathrm{GP})(\mathrm{N} \times 6.25)$ was determined. Total chlorophyll contents in foliage were determined at the early flowering stage (35 DAS) as suggested by Mechenny (1941). Total N content in the whole plant was measured at the flowering and podfill stages by the Kjeldahl method (Jackson, 1958). The data of measured parameters recorded for two years were pooled together and subjected to statistical calculations using the Statistical Package for Social Science (SPSS for Windows package release 10.0; SPSS Inc, Chicago, IL) and significant differences between treatment means were evaluated at the $5 \%$ level of probability.

\section{RESULTS AND DISCUSSION}

\subsection{Plant growth}

Greengram plants grown with three dose rates of four herbicides showed a varied plant growth (Tab. I). The effects of lower rates $\left(0.5\right.$ and $1 \mu \mathrm{g}$ a.i. $\left.\mathrm{g}^{-1}\right)$ of herbicides on root and 
Table I. Effect of three dose rates of glyphosate, metribuazin, fluchloralin and 2,4-D on length and dry matter production 60 days, chlorophyll content 35 days and seed yield 75 days after seeding inoculated greengram and inoculated but herbicide-free control.

\begin{tabular}{|c|c|c|c|c|c|c|c|c|}
\hline \multirow[t]{2}{*}{ Herbicides } & \multirow{2}{*}{$\begin{array}{l}\text { Dose rate } \\
\left(\mu \mathrm{g} \text { a.i. } \mathrm{g}^{-1}\right)\end{array}$} & \multicolumn{2}{|c|}{ Length (cm) } & \multicolumn{4}{|c|}{ Dry weight (g/plant) } & \multirow{2}{*}{$\begin{array}{c}\text { Total } \\
\text { chlorophyll } \\
\text { (mg/g) }\end{array}$} \\
\hline & & Root & Shoot & Root & Shoot & $\begin{array}{c}\text { Total } \\
\text { biomass }\end{array}$ & $\begin{array}{c}\text { Grain } \\
\text { (g/1000 seed) }\end{array}$ & \\
\hline \multirow[t]{3}{*}{ Glyphosate } & 0.5 & 12.1 & 31.7 & 0.49 & 1.96 & 2.45 & 40.5 & 3.13 \\
\hline & 1.0 & 10.6 & 28.8 & 0.51 & 1.90 & 2.41 & 38.2 & 3.09 \\
\hline & 2.0 & 6.2 & 22.8 & 0.54 & 1.88 & 2.42 & 33.0 & 2.90 \\
\hline \multirow[t]{3}{*}{ Metribuzin } & 0.5 & 4.6 & 12.6 & 0.12 & 0.90 & 1.02 & 24.0 & 0.92 \\
\hline & 1.0 & 4.2 & 10.5 & 0.09 & 0.65 & 0.74 & 16.0 & 0.64 \\
\hline & 2.0 & - & - & - & - & - & - & - \\
\hline \multirow[t]{3}{*}{ Fluchloralin } & 0.5 & 12.0 & 32.1 & 0.53 & 1.85 & 2.38 & 36.6 & 3.41 \\
\hline & 1.0 & 6.3 & 21.3 & 0.48 & 1.91 & 2.39 & 38.7 & 3.18 \\
\hline & 2.0 & 6.2 & 18.2 & 0.34 & 1.50 & 1.84 & 40.2 & 2.56 \\
\hline \multirow[t]{3}{*}{$2,4-\mathrm{D}$} & 0.5 & 10.6 & 26.5 & 0.29 & 1.52 & 1.81 & 38.3 & 2.05 \\
\hline & 1.0 & 9.8 & 24.6 & 0.20 & 1.30 & 1.50 & 37.2 & 2.54 \\
\hline & 2.0 & 9.7 & 18.7 & 0.12 & 1.10 & 1.22 & 34.3 & 1.72 \\
\hline Untreated control & & 11.7 & 28.5 & 0.52 & 1.92 & 2.44 & 36 & 3.20 \\
\hline $\operatorname{LSD}(0.05)$ & & 1.94 & 5.3 & 0.11 & 0.37 & 0.46 & 6.2 & 0.51 \\
\hline \multicolumn{9}{|l|}{ Contrast $a^{\mathrm{a}}$} \\
\hline $0.5 \mu$ g a.i. $\mathrm{g}^{-1}$ : Control vs. Glyphosate & & 0.4 & 3.2 & 0.03 & 0.04 & 0.01 & 4.5 & 0.07 \\
\hline Control vs. Metribuzin & & $7.1^{*}$ & $15.9^{*}$ & $0.40^{*}$ & $1.02^{*}$ & $1.42^{*}$ & $12^{*}$ & $2.28^{*}$ \\
\hline Control vs. Fluchloralin & & 0.3 & 3.6 & 0.01 & 0.07 & 0.06 & 0.6 & 0.21 \\
\hline Control vs. 2,4-D & & 1.1 & 2.0 & $0.23^{*}$ & $0.40^{*}$ & $0.63^{*}$ & 2.3 & $1.15^{*}$ \\
\hline $1 \mu \mathrm{g}$ a.i. $\mathrm{g}^{-1}$ : Control vs. Glyphosate & & 1.1 & 0.3 & 0.01 & 0.02 & 0.03 & 2.2 & 0.11 \\
\hline Control vs. Metribuzin & & $7.5^{*}$ & $18^{*}$ & $0.43^{*}$ & $1.27^{*}$ & $1.7^{*}$ & $20^{*}$ & $2.56^{*}$ \\
\hline Control vs. Fluchloralin & & $5.4^{*}$ & $7.2^{*}$ & 0.04 & 0.01 & 0.05 & 2.7 & 0.02 \\
\hline Control vs. 2,4-D & & 1.9 & $3.9^{*}$ & $0.32^{*}$ & $0.62^{*}$ & $0.94^{*}$ & 1.2 & $0.66^{*}$ \\
\hline $2 \mu \mathrm{g}$ a.i. $\mathrm{g}^{-1}$ : Control vs. Glyphosate & & $5.5^{*}$ & $5.7^{*}$ & 0.02 & 0.04 & 0.02 & 3.0 & 0.30 \\
\hline Control vs. Metribuzin & & - & - & - & - & - & - & - \\
\hline Control vs. Fluchloralin & & $5.5^{*}$ & $10.3^{*}$ & $0.18^{*}$ & $0.42^{*}$ & $0.60^{*}$ & 4.2 & $0.64^{*}$ \\
\hline Control vs. 2,4-D & & $2.0^{*}$ & $9.8^{*}$ & $0.40^{*}$ & $0.82^{*}$ & $1.22^{*}$ & 2.3 & $1.48^{*}$ \\
\hline
\end{tabular}

Values presented are means of 9 replicates where each replicate constituted 4 plants/pot. ${ }^{\text {a }}$ Difference between treatments. * In this and succeeding table indicates significant difference over control at $P \leq 0.05$. - Indicates complete inhibition.

shoot length of greengram plants, in general, was not statistically significant; except fluchloralin $\left(1 \mu \mathrm{g}\right.$ a.i. $\left.\mathrm{g}^{-1}\right)$ and metribuzin $\left(0.5\right.$ and $1 \mu \mathrm{g}$ a.i. $\left.\mathrm{g}^{-1}\right)$, which significantly $(P \leq 0.05)$ reduced the length of the plant parts (e.g. root and shoot). The average maximum reduction in root length $(64 \%)$ and shoot length $(63 \%)$ occurred at $1 \mu \mathrm{g}$ a.i. $\mathrm{g}^{-1}$ (metribuzin). Generally, the effects of these herbicides on plant parts increased gradually with an increase in rates of all herbicides. Metribuzin, at $2 \mu \mathrm{g}$ a.i. $\mathrm{g}^{-1}$, however, completely diminished the growth of inoculated greengram plants. Glyphosate and fluchloralin at 2 and $0.5 \mu \mathrm{g}$ a.i. $\mathrm{g}^{-1}$, respectively, marginally increased the dry matter accumulation in roots but decreased the shoot biomass compared with that observed for control plants. In contrast, metribuzin and 2,4-D at $0.5 \mu \mathrm{g}$ a.i. $\mathrm{g}^{-1}$ dramatically reduced the dry matter accumulation in roots (77\% for metribuzin and $44 \%$ for 2,4-D) and shoots (53\% for metribuzin and $21 \%$ for $2,4-\mathrm{D})$ and they were significantly lower than those obtained for the control treatment. The average maximum reduction in root and shoot biomass was obtained for metribuzin $\left(1 \mu \mathrm{g}\right.$ a.i. $\left.\mathrm{g}^{-1}\right)$ and the highest level $\left(2 \mu \mathrm{g}\right.$ a.i. $\left.\mathrm{g}^{-1}\right)$ of the tested herbicides. In general, all dose rates of metribuzin and 2,4-D and $2 \mu \mathrm{g}$ a.i. $\mathrm{g}^{-1}$ of fluchloralin significantly $(P \leq 0.05)$ decreased the whole dry weight of plants compared with the control treatment. Among the herbicides, metribuzin at $1 \mu \mathrm{g}$ a.i. $\mathrm{g}^{-1}$ and 2,4-D at $2 \mu \mathrm{g}$ a.i. $\mathrm{g}^{-1}$ showed more phytotoxic effect and reduced the total dry matter production in greengram plants significantly $(P \leq 0.05)$ by $69.6 \%$ and $50 \%$, respectively, as compared with control. While comparing the sum of mean values of 3 dose rates of each herbicide independently, the order of toxicity on total biomass production in greengram increased in the following order: glyphosate $<$ fluchloralin $<2,4-\mathrm{D}<$ metribuzin.

The toxicity of various herbicides to nodule bacteria in vitro or legume plants varies widely, and often compounds with the greatest herbicidal activity are the most damaging to both Rhizobium and legumes. Herbicides, therefore, affect the viability of rhizobia and thus affect the mechanism involved in 
Bradyrhizobium - greengram symbiosis. Herbicide is, however, applied to reduce the competition from weeds and consequently to augment the yield of agronomic crops: but their use may be incongruous regarding the establishment of an effective symbiotic relationship between nodule bacteria and legume host plant. In the present study, the trend observed suggests that the lower dose rates of herbicides in general did not affect the growth and dry matter production negatively, but rather stimulated the growth parameters in greengram. These studies, therefore, suggest that the lower rates might have persisted in the soil for only a short time period, after which the viable cells of Bradyrhizobium recovered and multiplied rapidly. This is possible because the soil environment can act as a buffer, reducing the potentially toxic effect by dilution of these chemicals (Castro et al., 1997). The higher concentrations of the tested herbicides, on the other hand, reduced the total dry matter production in greengram crops, possibly due to inhibition of aromatic amino acid biosynthesis (glyphosate), photosynthesis (metribuzin), the microtubule morphogenetic process (fluchloralin) and the premature senescence of the plants (2,4-D).

Glyphosate, a non-selective and phloem mobile herbicide, acts primarily on the shikimate pathway and blocks the synthesis of aromatic amino acids (AAA) and other phenolic compounds, including cinnamic acid (Canal et al., 1987), flavons (Ishikura et al., 1986) and flavanoids (Laanest, 1987). Presumably, the inhibition of AAA synthesis eventually leads to depletion of protein and therefore, lack of some essential protein function eventually leads to a decrease in plant growth. The phytotoxic action of glyphosate on total dry matter production could also be due to decreased starch synthesis (Greiger and Bestman, 1990), disruption of apical dominance (Lee, 1984), reduced endogenous hormone levels (Lee, 1984) and inhibition of the synthesis of chlorophyll (Kitchen et al., 1981a) and its precursor, $\delta$-aminolevulinic acid (ALA) (Kitchen et al., 1981b), or due to reduction in tubulin levels (Vaughan and Duke, 1986) and decreased nitrogenase activity (Malik and Tesfai, 1985).

Furthermore, the phytotoxic action of 2,4-D occurs largely as a result of its ability to mimic the activity of endogenous auxin. The excessively high concentrations of auxin-active herbicides, in turn, alters the regulation of plant metabolism, leading to the loss of cellular function, cellular integrity and repair capacities of plants (Nishitani and Masuda, 1981). When metribuzin was applied to sandy clay loam soils, it had a strong negative impact on plant vigor of inoculated greengram. In our

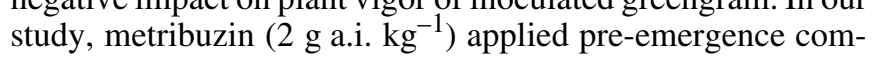
pletely diminished germination (data not shown). However, failure to germinate at a higher concentration of metribuzin could be attributed to the rupturing of seed testa and damage to the cell membranes, leading to the efflux of nutrients and other cellular contents. Similar evidence of phytotoxic activity of the pre-emergent application of metribuzin on germination and plant growth of soybean has previously been reported (Rennie and Dubetz, 1984). The effect of these herbicides on yield was also assessed.

\subsection{Seed yield}

The effects of herbicide treatments on seed yield was variable (Tab. I). Seed yield declined consistently with dose for all herbicides, but was only significantly reduced at $0.5(33.3 \%)$ and $1 \mu \mathrm{g}$ a.i. $\mathrm{g}^{-1}(55.5 \%)$ of metribuzin. In contrast, glyphosate, fluchloralin and 2,4-D at 0.5 and $1 \mu \mathrm{g}$ a.i. $\mathrm{g}^{-1}$, improved the grain yield relative to the control plants (Tab. I). The average maximum increase $(12.5 \%)$ in seed yield was observed with glyphosate $\left(0.5 \mu \mathrm{g}\right.$ a.i. $\left.\mathrm{g}^{-1}\right)$ compared with those obtained for herbicide-free but inoculated control. All herbicides at $2 \mu \mathrm{g}$ a.i. $\mathrm{g}^{-1}$, in general, showed no significant effect on seed production in greengram, except fluchloralin which increased the seed yield by $11.6 \%$ relative to the control. While comparing the sum of mean values of 3 dose rates of each herbicides independently, the order of toxicity on seed mass increased in the following order: fluchloralin $<$ glyphosate $<2,4-\mathrm{D}<$ metribuzin.

In the present study, seed yield declined consistently with dose for all herbicides, except fluchloralin, which suggested that the increase in yield might be primarily due to the increase in plant stand. Treatments, e.g. fluchloralin, that adversely affected nodulation at higher rates did not adversely affect seed production. Apparently, plants compensated for the temporary reduction in $\mathrm{N}$ contribution via $\mathrm{N}_{2}$ fixation, which allowed $\mathrm{N}$ reserves in plants with a nitrogen fixation process that was temporarily suppressed to be sufficient later to meet seed production demands. In contrast, the lower doses of herbicides may have stimulated the plant physiological process, which in turn resulted in higher crop yield. In other studies, benefin, dintramine and nitralin at recommended levels decreased pod yields of groundnut cultivars, while fluchloralin at the same rate enhanced the yield (Durgesha, 1994). Furthermore, the herbicides were used to evaluate their effects on chlorophyll content in greengram foliage.

\subsection{Chlorophyll content}

The effect of herbicide treatments on chlorophyll content in foliage at the flowering stage (35 DAS) consistently declined with increasing rates of herbicides but was significant $(\mathrm{P} \leq 0.05)$ only at 0.5 and $1 \mu \mathrm{g}$ a.i. $\mathrm{g}^{-1}$ of metribuzin and 2,4-D and $2 \mu \mathrm{g}$ a.i. $\mathrm{g}^{-1}$ of all herbicides except glyphosate (Tab. I). Conversely, fluchloralin $\left(0.5 \mu \mathrm{g}\right.$ a.i. $\left.\mathrm{g}^{-1}\right)$ improved the chlorophyll content in foliage by $7 \%$ at the flowering stage, as compared with control. Among the herbicide and dose rates, metribuzin $\left(1 \mu \mathrm{g}\right.$ a.i. $\left.\mathrm{g}^{-1}\right)$ had the greatest adverse effect and reduced the chlorophyll content by $80 \%$. In comparison, $2,4-\mathrm{D}$ at 1 and $2 \mu \mathrm{g}$ a.i. $\mathrm{g}^{-1}$ decreased the chlorophyll content by 20.6 and $46.3 \%$, respectively, compared with the control plants.

In many physiological studies on herbicides, the reduction in photosynthetic pigments has been related to an inhibition in photosynthesis. For instance, metribuzin inhibits photosynthesis by blocking electron transfer from compound Q to plastoquinone in photosystem II (Fedtke, 1982) and hence prevents the reduction of $\mathrm{NADP}^{+}$required for $\mathrm{CO}_{2}$ fixation. The phytotoxic symptoms (leaf chlorosis and necrosis) of metribuzin occur a few days after herbicide application. Thus, the herbicide damage was possibly as a consequence of singlet oxygen action that damaged the enzymes and membrane of the chloroplast. Chloroplasts, though, have various mechanisms to scavenge toxic oxygen species, but in the present study they were overwhelmed by the level of oxidative stress generated. These results therefore give credence to those observed for plant growth, which showed a negative impact of metribuzin on plants grown for 60 days in sterilized soil. Further, the pigment 
Table II. Effect of three dose rates of glyphosate, metribuazin, fluchloralin and 2,4-D on nodulation and N content 35 and 60 days and grain protein 75 days after seeding inoculated greengram and inoculated but herbicide-free control.

\begin{tabular}{|c|c|c|c|c|c|c|c|c|}
\hline \multirow[t]{3}{*}{ Herbicides } & \multirow{3}{*}{$\begin{array}{l}\text { Dose rate } \\
\left(\mu \mathrm{g} \text { a.i. } \mathrm{g}^{-1}\right)\end{array}$} & \multicolumn{4}{|c|}{ Nodule } & \multirow{2}{*}{\multicolumn{2}{|c|}{$\begin{array}{l}\mathrm{N} \text { content in whole plant } \\
\qquad\left(\mathrm{mg} \mathrm{plant}^{-1}\right)\end{array}$}} & \multirow{3}{*}{$\begin{array}{c}\text { Grain } \\
\text { protein }(\mathrm{GP}) \\
(\%)\end{array}$} \\
\hline & & \multicolumn{2}{|c|}{ Number/plant } & \multicolumn{2}{|c|}{$\begin{array}{l}\text { Dry weight } \\
\left(\mathrm{mg} \mathrm{plant}^{-1}\right)\end{array}$} & & & \\
\hline & & 35 DAS & 60 DAS & 35 DAS & 60 DAS & 35 DAS & 50 DAS & \\
\hline \multirow[t]{3}{*}{ Glyphosate } & 0.5 & 36 & 32 & 29.6 & 21.4 & 48.2 & 24.0 & 24 \\
\hline & 1.0 & 34 & 30 & 28.4 & 17.2 & 46.6 & 22.6 & 23 \\
\hline & 2.0 & 18 & 16 & 24.8 & 13.6 & 20.5 & 11.6 & 15 \\
\hline \multirow[t]{3}{*}{ Metribuzin } & 0.5 & 10 & 8 & 6.0 & 4.8 & 16.5 & 10.5 & 10 \\
\hline & 1.0 & 7 & 5 & 4.2 & 3.0 & 15.6 & 8.5 & 8 \\
\hline & 2.0 & - & - & - & - & - & - & - \\
\hline \multirow[t]{3}{*}{ Fluchloralin } & 0.5 & 34 & 33 & 25.6 & 19.2 & 54.4 & 21.6 & 22 \\
\hline & 1.0 & 32 & 30 & 23.8 & 10.8 & 50.3 & 20.7 & 20 \\
\hline & 2.0 & 22 & 16 & 13.2 & 9.6 & 43.7 & 18.0 & 18 \\
\hline \multirow[t]{3}{*}{$2,4-\mathrm{D}$} & 0.5 & 26 & 29 & 21.0 & 23.8 & 42.6 & 17.5 & 17 \\
\hline & 1.0 & 24 & 30 & 18.0 & 18.2 & 27.2 & 13.5 & 16 \\
\hline & 2.0 & 20 & 26 & 15.6 & 17.4 & 20.7 & 12.2 & 14 \\
\hline Untreated control & & 32 & 28 & 25.6 & 22.4 & 56.3 & 22.6 & 20 \\
\hline LSD (0.05) & & 5.5 & 4.5 & 3.6 & 3.9 & 9.8 & 3.5 & 3.4 \\
\hline \multicolumn{9}{|l|}{ Contrast at ${ }^{\mathrm{a}}$} \\
\hline $0.5 \mu \mathrm{g}$ a.i. $\mathrm{g}^{-1}$ : Control vs. Glyphosate & & 4 & 4 & $4.0^{*}$ & 1.0 & 8.1 & 1.4 & $4^{*}$ \\
\hline Control vs. Metribuzin & & $22^{*}$ & $20^{*}$ & $19.6^{*}$ & $17.6^{*}$ & $39.8^{*}$ & $12.1^{*}$ & $10^{*}$ \\
\hline Control vs. Fluchloralin & & 2 & $5^{*}$ & 0.0 & 3.2 & 1.9 & 1.0 & 2 \\
\hline Control vs. 2,4-D & & $6^{*}$ & 1 & $4.6^{*}$ & 1.4 & $13.7^{*}$ & $5.1^{*}$ & 3 \\
\hline $1 \mu \mathrm{g}$ a.i. $\mathrm{g}^{-1}$ : Control vs. Glyphosate & & 2 & 2 & 2.8 & $5.2^{*}$ & 9.7 & 0.0 & 3 \\
\hline Control vs. Metribuzin & & $25^{*}$ & $23^{*}$ & $21.4^{*}$ & $19.4^{*}$ & $40.7^{*}$ & $14.1^{*}$ & $12^{*}$ \\
\hline Control vs. Fluchloralin & & 0 & 2 & 1.8 & $11.6^{*}$ & 6.0 & 1.9 & 0 \\
\hline Control vs. 2,4-D & & $8^{*}$ & 2 & $7.6^{*}$ & $4.2^{*}$ & $29.1^{*}$ & $9.1^{*}$ & $4^{*}$ \\
\hline $2 \mu \mathrm{g}$ a.i. $\mathrm{g}^{-1}$ : Control vs. Glyphosate & & $14^{*}$ & 12 & 0.8 & $8.8^{*}$ & $35.8^{*}$ & $11.0^{*}$ & $5^{*}$ \\
\hline Control vs. Metribuzin & & - & - & - & - & - & - & 0 \\
\hline Control vs. Fluchloralin & & $10^{*}$ & $12^{*}$ & $12.4^{*}$ & $12.8^{*}$ & $12.6^{*}$ & $4.6^{*}$ & 2 \\
\hline Control vs. 2,4-D & & $12^{*}$ & 2 & $10.0^{*}$ & $5.0^{*}$ & $35.6^{*}$ & $10.4^{*}$ & $6^{*}$ \\
\hline
\end{tabular}

deficiency in the foliage of greengram plants may be caused either by photobleaching (Barry et al., 1990) or by inhibition of biosynthesis of either chlorophyll or carotenoids (Sandmann and Boger, 1987). Additionally, the detrimental effects of metribuzin applied to legumes are postulated to be due to a decreased supply of photosynthate to the roots rather than to direct phytotoxic effects on inoculation and $\mathrm{N}_{2}$ fixation (Berthelot and Clark, 1985). The data from this study thus support the concept that the detrimental effect of metribuzin is primarily plantmediated, that resulted in the indirect effects on nodulation and yield. Similar evidence of phytotoxic action of photosynthesisinhibiting herbicides on both inoculated and non-inoculated legumes has previously been reported (Malik and Tesfai, 1985; Sprout et al., 1991). Furthermore, the effects of the four herbicides on symbiotic traits of greengram were assessed.

\subsection{Symbiotic traits}

Nodulation response to the three dose rates of the four herbicides at 35 (flowering) and 60 (pod-fill stage) days after seeding greengram varied considerably (Tab. II). In the present study, nodulation had occurred on virtually $100 \%$ of all roots of the greengram plants, when grown in the greenhouse, by day seven (data not shown). Furthermore, large-sized nodules were located on the main roots while the small-sized nodules were scattered all through the adventitious roots. Comparison between herbicide-free control and each herbicide treatment revealed a marginal increase in the number of nodules per plant following 0.5 and $1 \mu \mathrm{g}$ a.i. $\mathrm{g}^{-1}$ of glyphosate at the flowering and pod-fill stages, while fluchloralin at $0.5 \mu \mathrm{g}$ a.i. $\mathrm{g}^{-1}$ significantly $(P \leq 0.05)$ improved the number of nodules per plant 
by $17.8 \%$, at the pod-fill stage only. In contrast, metribuzin at 0.5 and $1 \mu \mathrm{g}$ a.i g $\mathrm{g}^{-1}$ dramatically decreased the number of nodules per plant at the flowering and pod-fill stages, compared with those obtained for control plants. Furthermore, all dose rates of 2,4-D decreased the number of nodules per plant by $18.8 \%\left(0.5 \mu \mathrm{g}\right.$ a.i. $\left.\mathrm{g}^{-1}\right)$ to $37.5 \%\left(2 \mu \mathrm{g}\right.$ a.i. $\left.\mathrm{g}^{-1}\right)$ at the flowering stage while at the pod-fill stage, no significant adverse effect of any concentrations of this herbicide was observed. Comparison between the herbicide-free control pots and each herbicide treatment showed that the reduction in nodulation was accompanied by a significant decrease in dry mass of nodules at both the flowering and pod-fill stages. All dose rates of 2,4-D, $2 \mu \mathrm{g}$ a.i. $\mathrm{g}^{-1}$ of fluchloralin and 0.5 and $1 \mu \mathrm{g}$ a.i. $\mathrm{g}^{-1}$ of metribuzin significantly $(P \leq 0.05)$ reduced the dry mass of nodules at the flowering stage. Conversely, 0.5 and $1 \mu \mathrm{g}$ a.i. $\mathrm{g}^{-1}$, of glyphosate enhanced the dry mass of nodules only at the flowering stage by 15.6 and $11 \%$, respectively. In general, the herbicidal impact was more profound at the pod-fill stage compared with the flowering stage of greengram.

Infection of the roots of legumes by rhizobia in general takes place through the root hairs so that the process of nodulation of legumes is undoubtedly linked to the expansion of the various parts of the root system. Therefore, it is possible that a herbicide which induces a reduction in the nodules formed per plant may do this by restricting root growth and/or formation of lateral roots, and hence the number of root sites available for infection. Generally, the lower rates of herbicide used in the present study improved the nodulation in greengram, possibly because at a sublethal dose, the herbicide may have induced damage to the xylem vessel without adversely affecting the nodular bacteroids and, hence, the greengram - Bradyrhizobium symbiosis remained unaffected. In the present study, the root weight and number of nodules formed per plant were both reduced following herbicide applications, but glyphosate improved the root growth at $2 \mu \mathrm{g}$ a.i. $\mathrm{g}^{-1}$ and nodulation at 0.5 and $1 \mu \mathrm{g}$ a.i. $\mathrm{g}^{-1}$. The lack of inhibitory effect on nodulation observed with glyphosate could be due to its rapid inactivation in soils (Eberbach and Douglas, 1983) or its rapid translocation, along with photosynthate, to a distant metabolic sink.

Furthermore, the herbicide-induced decline in nodulation following herbicidal application, in general, could be due to the inhibition of the symbiosis between the legume (greengram) root and the bacteria (Bradyrhizobium). However, among the four herbicide and dose rates, metribuzin in general had a greater adverse effect on nodule formation, suggesting that this herbicide is highly toxic for Bradyrhizobium-greengram symbiosis. In addition, the reduction in nodulation could possibly be due to a strong decrease in nitrogenase activity, which can be associated with damage in the photosynthetic apparatus and also with alteration in the nodule cortex structure. In both cases, the cytosolic catalase and peroxidase are altered by metribuzin application, suggesting nodule senescence (Fernandez Pascual et al., 1992). Conversely, fluchloralin at lower dose rates improved the root growth and the number of nodules, and hence, suggests that the effect of fluchloralin on the process of nodulation of greengram was dependent on the effect of this herbicide on the growth of the host plant. On the contrary, the root weight and number of nodules formed per plant were both reduced by 2,4-D and correlation between root weight and nodule number was highly significant at the flowering $(r=0.97)$ and pod-fill stages $(r=0.55)$. Thus, the correlation between these two parameters indicates that this herbicide either interfered with the process of nodule initiation directly or the observed reduction in nodulation was related to the reduction in the root system of greengram plants. However, the decline in rhizobial populations within nodules following herbicidal applications may also be one of the reasons for reduced Bradyrhizobium-greengram symbiosis. Similar evidence of toxicity of herbicides on nodulation and $\mathrm{N}_{2}$ fixation in soybean (Malik and Tesfai, 1985) and chickpea (Khan et al., 2004) has previously been reported. The effect of the four herbicides on $\mathrm{N}$ content and protein content in grain is discussed in the following section.

\section{5. $N$ content}

The effect of herbicide treatments on $\mathrm{N}$ content in the whole plant (at 35 and 50 DAS) was variable (Tab. II). The average maximum reduction in $\mathrm{N}$ content in the whole plant occurred at 0.5 and $1 \mu \mathrm{g}$ a.i. $\mathrm{g}^{-1}$ of metribuzin and 2,4-D, at both 35 and 50 DAS, relative to the control treatment. Application of metribuzin at 0.5 and $1 \mu \mathrm{g}$ a.i. $\mathrm{g}^{-1}$ resulted in a maximum reduction (70.7 and $72.3 \%$ at 35 DAS and 53.3 and $62.4 \%$ at 60 DAS, respectively) in $\mathrm{N}$ content in the whole plant. In comparison, glyphosate and fluchloralin at the same dose rates did not show any significant $(P \leq 0.05)$ adverse effect on $\mathrm{N}$ content in greengram plants. However, the maximum reduction in $\mathrm{N}$ contents at $2 \mu \mathrm{g}$ a.i. $\mathrm{g}^{-1}$ was observed for glyphosate (63.6 and $48.6 \%$ at 35 and 60 DAS, respectively) which was followed by 2,4-D (63.2 and $46 \%$ at 35 and 60 DAS, respectively) compared with the control treatment. Generally, the $\mathrm{N}$ contents declined with increasing dose rates for all herbicides at both 35 and 60 DAS. Nitrogen contents in the whole plant following herbicidal applications were higher at 35 DAS compared with those obtained at 60 DAS, but were less than those of the inoculated control plants at each stage of plant growth. The total $\mathrm{N}$ concentration in the whole greengram plants following herbicidal application was invariably affected both at 35 and 60 DAS, which suggested that the plant compensated for reduced nodule activity by increased uptake of soil N. Similar studies have also demonstrated a significant reduction in $\mathrm{N}$ contents in the shoots of plants when applying commercial herbicides, including bentazone, isoproturon, fluchloralin and 2,4-D, to chickpea under controlled conditions (Khan et al., 2004).

\subsection{Grain protein}

The effect of three rates of the four herbicides on grain protein was variable (Tab. II). The average maximum grain protein $\left(24 \%\right.$ GP) was obtained at $0.5 \mu \mathrm{g}$ a.i. $\mathrm{g}^{-1}$ of glyphosate, and was significantly different from inoculated but herbicide-free control. In comparison, metribuzin and 2,4-D at $0.5 \mu \mathrm{g}$ a.i. $\mathrm{g}^{-1}$ reduced the protein concentrations in grains by 50 and $15 \%$, respectively. The average maximum reduction in \% GP $(60 \%)$ was observed with metribuzin $\left(1 \mu \mathrm{g}\right.$ a.i. $\left.\mathrm{g}^{-1}\right)$ which was followed by 2, 4-D $\left(2 \mu \mathrm{g}\right.$ a.i. $\left.\mathrm{g}^{-1}\right)$ as compared with control treatment. However, all rates of fluchloralin did not show any significant adverse effect on \% GP of greengram. In general, the protein content in grains declined gradually with increasing rates of all herbicides. While comparing the sum of the mean 
values of 3 dose rates and each treatment, the order of toxicity on $\%$ GP of inoculated greengram increased in the following order: glyphosate $<$ fluchloralin $<2,4-\mathrm{D}<$ metribuzin.

Protein content in grains of greengram was found to be the most important parameter that was severely affected by the highest dose rates of glyphosate and fluchloralin and all the tested rates of metribuzin and 2,4-D. Generally, the protein contents were below the normal range under most of the treatment conditions. The reduction in the protein content thus suggested that the enzymes and other functional proteins are one of the target sites of herbicide toxicity, which subsequently leads to alteration in the protein metabolism of grains. The direct effect of herbicides on protein contents in seeds is difficult to interpret. However, the indirect effect of these herbicides on various metabolisms of the plants and their symbiotic partner (Bradyrhizobium) possibly led to decreased availability of $\mathrm{N}$ to the seed or $\mathrm{N}$ uptake by seeds, which in turn adversely affected the grain protein. A similar reduction in protein content in legume grains has previously been reported by others (Fernandez Pascual et al., 1992; Malik and Tesfai, 1985).

In conclusion, although metribuzin clearly exhibited a strong inhibitory effect on inoculated greengram, the differences between the present study and previous reports and conflict in the literature indicates the complexity of the subject. However, the lack of effective nitrogen fixation following herbicidal applications resulted in substantial loss in the yield of greengram. Based on the present findings of the two-year trials in sterilized soils, we therefore suggest that the greengram growers, who often adopt intensive agricultural practices with herbicides, use glyphosate and fluchloralin, because these herbicides may safely be used without adversely affecting the vitality and yield of greengram. The application of metribuzin to control weeds in a greengram cultivation system should be avoided. The applicability of this approach, however, has to be tested further in field studies.

Acknowledgments: We would like to thank the Indian Agricultural Research Institute, New Delhi, India for providing the rhizobial culture and technical-grade herbicides used during the study. We are also grateful to the Department of Computer Applications of this university for statistical analysis of the data.

\section{REFERENCES}

Aamil M., Zaidi A., Khan M.S. (2002) Effects of herbicide dose rates on growth, nodulation and yield in chickpea (Cicer arietinum L.), Ann. Appl. Biol. (Suppl. TAC) 23, 8-9.

Aamil M., Zaidi A., Khan M.S. (2004) Effect of herbicides on growth, nodulation and yield of chickpea (Cicer arietinum L.), Ann. Pl. Protec. Sci. 12, 186-191.

Avron O.E. (1966) Effect of herbicides on nodule formation in legumes, Soils Fertil. 29, 454.

Barry P., Young A.J., Briton G. (1990) Photodestruction in higher plants by herbicide action, J. Exp. Bot. 41, 123-126.

Bertholet J., Clark K.W. (1985) Effect of trifluralin and metribuzin on faba bean growth, development and symbiotic nitrogen fixation, Can. J. Pl. Sci. 56, 9-21.
Billore S.D., Joshi O.P., Ramesh A. (2001) Effect of herbicides on nodulation, yield and weed control in soybean (Glycine max), Indian J. Agr. Sci. 71, 193-194.

Bollich P.K., Denigan E.P., Kitchen L.M., Burn R.C. (1985) The influence of trifluralin and pendimethalin on nodulation, $\mathrm{N}_{2}\left(\mathrm{C}_{2} \mathrm{H}_{2}\right)$ fixation and seed yield of field grown soybean (Glycine max L.), Weed Res. 36, 15-19.

Canal M.J., Tames R.S., Fernandez B. (1987) Glyphosate increased levels of indole -3-acetic acid in yellow nutsedge leaves correlated with gentisic acid levels, Physiol. Plant 71, 384-388.

Castro S., Vinocur M., Permigiani M., Carlos H., Taurian T., Fabra A. (1997) Interaction of the fungicide mancozeb and Rhizobium sp. in pure culture and under field conditions, Biol. Fert. Soils 25, 147151.

Durgesha M. (1994) Effect of dinitroaniline herbicides on rhizobia, nodulation and $\mathrm{N}_{2}\left(\mathrm{C}_{2} \mathrm{H}_{2}\right)$ fixation of 4 groundnut cultivars, Ann. Appl. Biol. 124, 75-82.

Eberbach P.L., Douglas L.A. (1983) Persistence of glyphosate in a sandy loam soil, Soil Biol. Biochem. 15, 485-487.

Fedtke C. (1982) Biochemistry and physiology of herbicide action, Springer-Verlag, Berlin.

Fernandez Pascual M., Delerenzo C., Pozuelo J.M., Defelipe M.R. (1992) Alterations induced by 4 herbicides on lupin nodule cortex structure, protein metabolism and some senescence related enzymes, J. Plant, Physiol. 140, 385-390.

Greiger D.R., Bestman H.D. (1990) Self limitation of herbicide mobility by phytotoxic action, Weed Sci. 38, 324-329.

Heinonen-Tanski H., Oros G., Kecskes M. (1982) The effect on soil pesticides on the growth of red clover rhizobia, Acta Agr. Scand. 32, $283-288$.

Hernandez A., Gracia-Plazaola J.I., Becerril J.M. (1999) Glyphosate effects on phenolic metabolism of nodulated soybean (Glycine max L. Merr.), J. Agric. Food Chem. 47, 2920-2925.

Hoagland D.R., Arnon D.I. (1938) The water culture method for growing plants without soil, Calif. Agric. Exp. Sta. Circ. No. 347.

Ishikura N., Teramoto S., Takeshima Y., Mitsui S. (1986) Effects of glyphosate on the shikimate pathway and regulation of phenyl alanine ammonia-lyase in Cryptomeria and Perilla cell suspension cultures, Plant Cell Physiol. 27, 677-684.

Jackson M.L. (1958) Soil Chemical Analysis, Prentice Hall of India Pvt. Ltd., New Delhi.

Khan M.S., Zaidi A., Aamil M. (2004) Influence of herbicides on chickpea Mesorhizobium symbiosis, Agronomie 24, 123-127.

Kitchen L.M., Witt W.W., Rieck L.E. (1981a) Inhibition of $\delta$-aminolevulinic acid synthesis by glyphosate, Weed Sci. 29, 571-577.

Kitchen L.M., Witt W.W., Rieck L.E. (1981b) Inhibition of chlorophyll accumulation by glyphosate, Weed Sci. 29, 513-516.

Laanset L. (1987) Incorporation of exogenous tyrosine and phenyl alanine into c- glycosylflavones in glyphosate treated barley seedlings, Eesti NSV Tead. Akad. Toim. Biol. 36, 204-209.

Lee T. (1984) Release of lateral buds from apical dominance by glyphosate in soybean and pea seedlings, J. Plant Growth Regul. 3, 227235 .

Mallik M.A.B., Tesfai K. (1983) Compatibility of Rhizobium japonicum with commercial pesticides in vitro, Bull. Env. Contam. Toxicol. 31, 432-437.

Mallik M.A.B., Tesfai K. (1985) Pesticidal effect on soybean rhizobia symbiosis, Plant Soil 85, 33-41. 
McWhorter C.G. (1985) The physiological effects of adjuvants on plants, in: Duke S.O. (Ed.), Weed Physiology, Vol. II. Herbicide Physiology, CRC Press, Boca Raton, FL, pp. 141-158.

Mechenny G. (1941) Absorption of light by chlorophyll solution, J. Biol. Chem. 140, 315-320.

Nishitani K., Masuda Y. (1981) Auxin induced changes in the cell wall structure, changes in the sugar composition, intrinsic viscosity and molecular weight distribution of matrix polysaccharides of the epicotyl cell of vigna angularis, Physiol. Plant 52, 482-494.

Pahwa S.K., Prakash J. (1992) Effect of some herbicides on the growth, nodulation and $\mathrm{N}_{2}$ fixation in chickpea (Cicer arietinum L.), Indian J. Plant Physiol. 35, 207-212.

Pahwa S.K., Prakash J., Sharma H.R. (1988) Effect of herbicides on the growth, nodulation and symbiotic nitrogen fixation in pigeonpea (Cajanus cajan (L.)Mill sp.), Crop. Res. 131, 140.

Pandey R.K., Rai S.N. (1995) Effect of pesticides on nodulation, yield and $\mathrm{N}$ uptake by soybean (Glycine max), Madras Agric. J. 82, 115119 .
Rennie R.J., Dubetz S. (1984) Effect of fungicides and herbicides on the nodulation and $\mathrm{N}_{2}$ fixation in soybean fields lacking indigenous Rhizobium japonicum, Agron. J. 76, 451-454.

Sandman G., Boger P. (1987) Herbicides affecting plant pigments, in: Proc. Brit. Crop. Prot. Conf. Weeds, Vol. 1, BCPC Publ., Thornton Heath, UK, pp. 139-148.

Sharma S.K. (2000) Greengram, in: Rathore R.S. (Ed.), Techniques and Management of field crop production, Agrobios, New Delhi, India, pp. 284-294.

Silva J.C.C., Colaco W., Burity H.D., Ferreira N.C.M., Figuweiredo M.V.B., Martinez C.R. (1998) Herbicides on nodulation and $\mathrm{N}_{2}$ fixation in cowpea, Pesquisa Agropecu. Bras. 33, 77-86.

Singh G., Wright D. (2002) In vitro studies on the effect of herbicides on the growth of rhizobia, Let. Appl. Microbiol. 35, 12-16.

Sprout S.L., Nelson L.M., Germida J.J. (1991) Influence of metribuzin on the Rihizobium leguminosarum-lentil symbiosis, Can. J. Microbiol. 38, 243-249.

Towne C.A., Bartels P.G., Hilton J.L. (1978) Interaction of surfactant and herbicide treatments on single cell of leaves, Weed Sci. 26, 182-188.

Vaughan K.C., Duke S.O. (1986) Ultrastructural effects of glyphosate on Glycine max seedlings, Pestic. Biochem. Physiol. 26, 56-65.

To access this journal online: www.edpsciences.org 